Provided for non-commercial research and education use. Not for reproduction, distribution or commercial use.

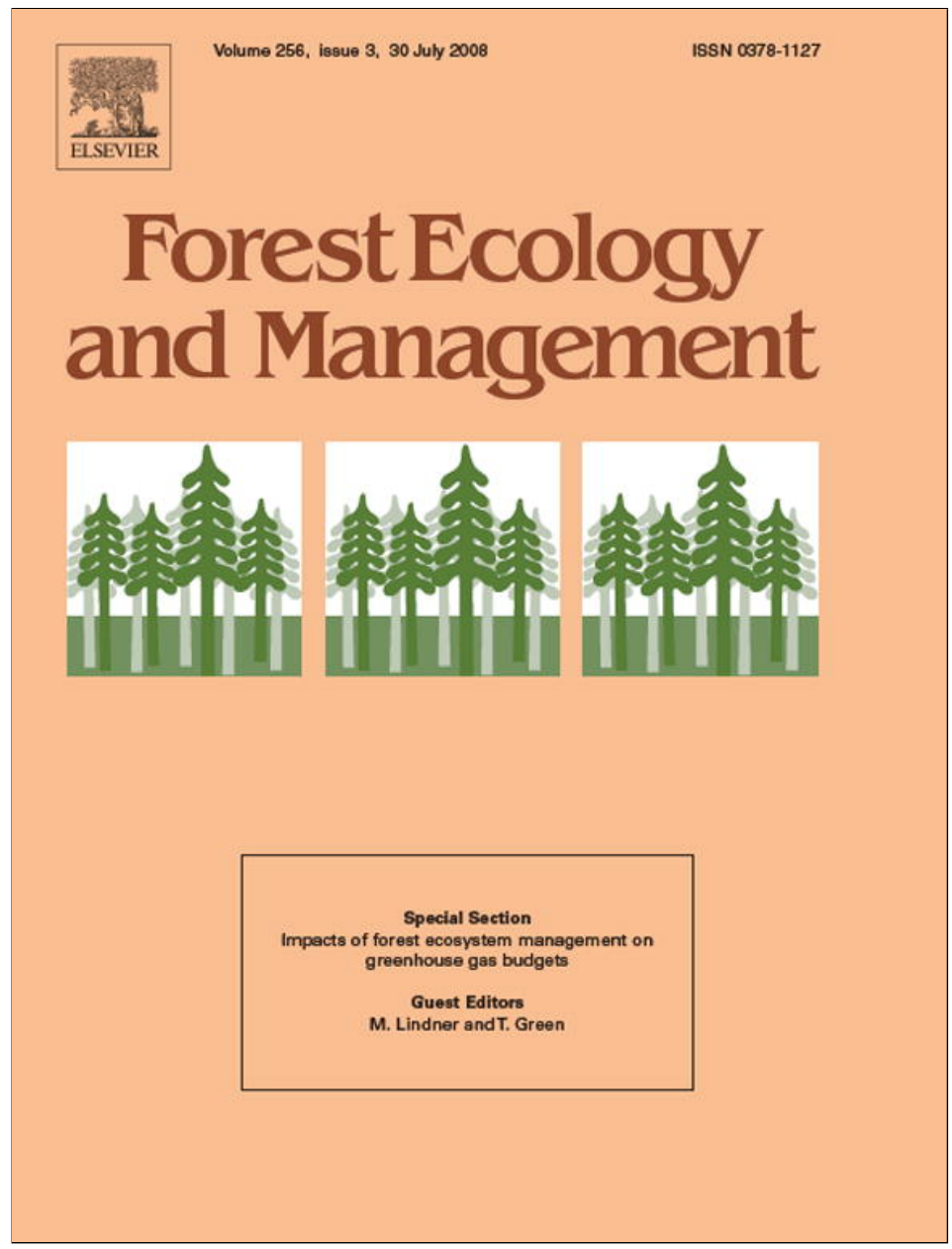

This article appeared in a journal published by Elsevier. The attached copy is furnished to the author for internal non-commercial research and education use, including for instruction at the authors institution and sharing with colleagues.

Other uses, including reproduction and distribution, or selling or licensing copies, or posting to personal, institutional or third party websites are prohibited.

In most cases authors are permitted to post their version of the article (e.g. in Word or Tex form) to their personal website or institutional repository. Authors requiring further information regarding Elsevier's archiving and manuscript policies are encouraged to visit:

http://www.elsevier.com/copyright 


\title{
Growth and survival of termite-piped Eucalyptus tetrodonta and E. miniata in northern Australia: Implications for harvest of trees for didgeridoos
}

\author{
Patricia A. Werner ${ }^{\mathrm{a}, \mathrm{b}, \mathrm{c}, *}$, Lynda D. Prior ${ }^{\mathrm{c}}$, Josh Forner ${ }^{\mathrm{b}, \mathrm{c}}$ \\ a The Fenner School of Environment and Society, W.K. Hancock Building 43, Australian National University, Canberra, ACT 0200, Australia \\ ${ }^{\mathrm{b}}$ Faculty of Education, Health, and Science, Charles Darwin University, Darwin, NT 0909, Australia \\ ' School for Environmental Research, Charles Darwin University, Darwin, NT 0909, Australia
}

A R T I C L E I N F O

\section{Article history:}

Received 13 August 2007

Received in revised form 15 April 2008

Accepted 20 April 2008

\section{Keywords:}

Eucalyptus

Nutrient cycling

Savanna

Termites

Tree growth

Tree hollows

Tree mortality

\begin{abstract}
A B S T R A C T
The most common canopy trees in the savannas of northern Australia, Eucalyptus tetrodonta and E. miniata are also two of the most common species harvested to make didgeridoos, the traditional musical instrument of northern Australian Aboriginal peoples now experiencing high demand from international markets. Most of the trees of the area naturally have hollow cores, or pipes, due to termite activity, but little is known of the relationships of the cores to size of tree, tree growth or survival. In a wooded savanna of northern Australia, 267 individual trees with known growth and survival rates were cored to determine degree of termite-piping. Generalized linear modelling and multi-model inference showed that frequency of piping increased with diameter $(\mathrm{dbh})$ tree for E. tetrodonta, but $>85 \%$ of $E$. miniata trees were piped regardless of $\mathrm{dbh}$. Growth (dbh increment) and survival (4-year) were size-dependent. Survival of both species decreased strongly with degree of piping (pipe ratio). For any given diameter, the growth rate of E. miniata trees was independent of pipe ratio, but for $E$. tetrodonta trees decreased strongly with pipe ratio. From modelled data, a $10-\mathrm{cm}$ tree with pipe ratio of 0.60 was very vulnerable, growing at $0.0 \mathrm{~cm}$ year $^{-1}$ with $46 \%$ survival rate, whereas a $40-\mathrm{cm}$ tree, even with large pipe ratios $(0.80)$, grew $0.05 \mathrm{~cm}$ year $^{-1}$ with $98 \%$ survival rate. Traditional methods of tree harvesting remove only those smaller hollow trees that are already suffering low growth rates and are likely to die before reaching maturity, whereas current large-scale commercial methods also remove trees with higher growth and survival rates-those trees most likely to contribute to sustainable tree populations. Incorporating traditional selection and harvest methods into current commercial operations would help ensure longevity of this source of livelihood for indigenous peoples of the region.
\end{abstract}

(c) 2008 Elsevier B.V. All rights reserved.

\section{Introduction}

By far, the majority of trees in the eucalypt savannas of north central Australia have hollow cores, or pipes, attributable to termite activity, at frequencies of $66-89 \%$ over various surveys (Fox and Clark, 1972; Braithwaite, 1985; Forner, 1999; Werner and Prior, 2007). Recently, Werner and Prior (2007) demonstrated strong negative relationships between the degree of tree piping by termites and the growth and the survival of host trees within groups of eucalypts and of pantropical species. Further, the relationships were size-dependent, with the smallest trees most vulnerable to degree of stem piping. Results were not presented for individual species.

\footnotetext{
* Corresponding author at: The Fenner School of Environment and Society, W.K. Hancock Building 43, Australian National University, Canberra, ACT 0200, Australia Tel.: +61 26125 3381; fax: +61262150757.

E-mail addresses: wernerpa@ufl.edu (P.A. Werner),

lynda.prior@cdu.edu.au (L.D. Prior), J.Forner@darwin.nt.gov.au (J. Forner).
}

The two most common species in the Werner and Prior (2007) study were Eucalyptus tetrodonta F. Muell. and E. minata Cunn. Ex Schauer, major canopy trees of the savanna woodlands of northern Australia occurring from the Atherton Tableland to the Kimberley (Wilson et al., 1996). These two species often co-occur, prompting studies contrasting the species' physiologies or life history characteristics in order to understand their relative abundances and distribution in the landscape (Setterfield and Williams, 1996; Myers et al., 1997; Werner and Murphy, 2001; Werner, 2005; Prior et al., 2006; Cernusak et al., 2006; Lehmann, 2007). Differences between the two species in their responses to termite piping may potentially help explain differences in life histories recorded in previous field studies.

The species are also two of the three most common species used for the manufacture of didgeridoos, using both traditional and commercial methods (Cloake, 2002; Forner, 2006; Whitehead et al., 2006). Size-dependent life history responses to tree piping, such as shown by eucalypts as a whole (Werner and Prior, 2007) may have implications for the sustainability of harvest of these two 
commercially important species, depending on the size of trees taken at harvest. Traditionally, trees used to make didgeridoos were harvested individually, using customary methods to identify piped trees prior to harvest and based on very precise requirements in the dimensions of the timber, including the central hollow core of the main stem which then formed the basis of the didgeridoo (Forner, 1999). The increasing international demand for these musical instruments has resulted in current commercial operations that remove tens of thousands of trees (Taylor and Baker, 2002a) using both traditional, and increasingly, commercial methods whereby larger piped and unpiped trees are harvested, and mechanical means used to produce or widen the central core. In this way, several didgeridoos are obtained from a large single tree (Forner, 1999).

Our paper provides a comprehensive account of the consequences of tree-piping by termites on growth and survival of the two most important canopy species of the northern savannas which hereto were completely unstudied. We hypothesized that the relationships would be similar to those obtained for eucalypts and for pantropical species as a whole (Werner and Prior, 2007), but that the two species might exhibit different patterns, and hence termite piping could be added to the list of factors thought to influence relative abundance and distribution of the two tree species. Given the strong size-dependent results, there are also implications for the harvest of these two species in the manufacture of didgeridoos. Although this paper does not provide data sufficient for analysing the sustainability of harvesting operations per se, it does provide information that can contribute to these endeavours.

\section{Methods}

\subsection{Study area, study plots, and trees}

Field work was conducted in a eucalypt savanna $200 \mathrm{~km}$ east of Darwin, Northern Territory, in Kakadu National Park (KNP), specifically at the Kapalga Research Station $\left(12^{\circ} 34^{\prime} \mathrm{S}, 132^{\circ} 22^{\prime} \mathrm{E}\right)$. The geomorphology, soils, climate, and vegetation of Kakadu National Park are detailed in Russell-Smith (1995), Russell-Smith et al. (1995) and Findlayson and von Oertzen (1996), and those of Kapalga in Andersen et al. (2003). The most extensive savanna vegetation type (open forest) in northern KNP and the wider region occurs on well-drained soils, and is dominated by two tall (16$25 \mathrm{~m}$ ) evergreen eucalypts, stringybark (Eucalyptus tetrodonta) and/or Darwin woollybutt (E. miniata).

This study took advantage of the permanently marked plots and trees set up for a study of the effect of buffalo and fire on tree growth and demography (Werner, 2005). In that study, six permanent research sites were established in close proximity to each other in tall savanna woodland in Kapalga in September 1982; each consisting of five $30 \mathrm{~m} \times 30 \mathrm{~m}$ plots arranged on alternating sides of a $150-\mathrm{m}$ transect line. All trees $>1.4 \mathrm{~m}$ height in the plots were permanently marked and monitored for incremental growth and survival, annually, for 8 years (detail in Werner, 2005.). The two species of interest in this paper, E. tetrodonta and E. miniata, were restricted to 15 of the plots with the number of individual trees ( $n=165$ and 102, respectively) totalling about half of the 541 dicotyledenous trees. The individual trees are the same trees used for Werner (2005) and Werner and Prior (2007); all measurements on trees constitute individual observations.

\subsection{Field sampling of trees and calculations of growth, survival, and pipe ratio}

Diameters of all trees in the study plots were measured over bark to the nearest $0.05 \mathrm{~cm}$, at breast height $(1.5 \mathrm{~m})$, annually in
October at the end of the dry season to help reduce error in estimating incremental changes in diameter, using methods in Werner (2005). For the current study, we averaged growth increments for two intervals, 1984-1985 and 1985-1986, representing the years just prior and after termite sampling in 1985, and coincidentally, wet-seasons that were wetter and drier than average, $1685 \mathrm{~mm}$ vs. $1162 \mathrm{~mm}$ precipitation, respectively (Bureau of Meteorology, Jabiru Township; Werner, 2005). Trees did not experience fire during this period. Tree mortality for all trees alive in October 1985 was determined for the 4-year period 1985-1989; during this time, some trees experienced fire. During the course of this study, the area did not suffer high winds such as that due to cyclones.

In April 1985, all trees were bored with a tree coring tool to detect and measure the diameter of any hollow areas at breast height (1.4 m), using methods detailed in Werner and Prior (2007). The proportion of tree stem occupied by the hollow, termed the "pipe ratio", was calculated as the diameter of the hollow divided by the diameter of the tree at breast height. All statistical analyses were calculated using the data on pipes and tree diameters at breast height $(1.4 \mathrm{~m})$.

\subsection{Termites}

The most common tree-piping termite species in undisturbed savanna woodlands of the region is Coptotermes acinaciformis (Froggatt), accounting for more than $90 \%$ of the pipes in trees growing in natural areas (Fox and Clark, 1972; Braithwaite et al., 1988; Hodda, 1992; Andersen et al., 2005). These termites attack live trees usually from underground or occasionally through broken stems. It extends galleries through the heartwood, often eating into sapwood as well, producing a hollow pipe the entire length of the bole (Braithwaite et al., 1988; Andersen et al., 2005) and even into smaller branches and throughout the larger root system (Werner and Murphy, 2001 and unpublished data).

\subsection{Statistical analyses}

We employed multi-model inference based on information theory and model averaging, as in Werner and Prior (2007). A set of candidate models was developed to describe relationships between each response variable and possible explanatory variables; each candidate model set included a 'null' model, which describes the case where none of the possible explanatory variables have an effect. Akaike's information criterion for small sample sizes (AICc) was used to rank and weight the models (Burnham and Anderson, 2002). The AICc identified the model(s) most strongly supported by the data based on the bias-corrected, maximised log-likelihood of the fitted model and a penalty for the number of parameters used (Burnham and Anderson, 2002). Akaike weights were calculated for each model in the candidate set (Burnham and Anderson, 2002), and represent the weight of evidence in favour of a particular model as being the best model in the set. Designation of a single 'best' model is often unsatisfactory when there are several models receiving similar levels of support, but model averaging can provide a more stable and less biased estimate of effect size than any single best model. All analyses were performed using the $R$ statistical package V. 2.2.0 (R-Development Core Team, 2005).

This multi-model approach was used to assess the major influences on the frequency and severity of termite piping in $E$. tetrodonta and E. miniata trees, and to determine how much the piping was related to tree growth and survival. Specifically, we investigated: 


\section{Table 1}

Frequency of piping, diameter, and pipe ratio: AICc weights $\left(w_{i}\right)$ of models in candidate sets used to compare effects of initial tree diameter (initial dbh), species (E. tetrodonta or E. miniata), and their interaction on (i) frequency of termite piping in trees; (ii) pipe diameters in those trees piped by termites; (iii) pipe ratio

\begin{tabular}{|c|c|c|c|c|c|c|}
\hline \multirow[t]{2}{*}{ Response variable Model } & \multicolumn{2}{|c|}{ Frequency } & \multicolumn{2}{|c|}{ Pipe diameter } & \multicolumn{2}{|c|}{ Pipe ratio } \\
\hline & $w_{i}$ & Expdev & $w_{i}$ & Expdev & $w_{i}$ & Expdev \\
\hline Species $\times$ initial $\mathrm{dbh}$ & 0.186 & 11.34 & 0.180 & 6.90 & 0.071 & 2.07 \\
\hline Species + initial dbh & 0.503 & 11.30 & 0.225 & 6.79 & 0.186 & 2.00 \\
\hline Initial dbh & 0.306 & 9.88 & 0.595 & 6.78 & 0.083 & 0.40 \\
\hline Species & 0.005 & 6.11 & $<0.001$ & NA & 0.515 & 1.98 \\
\hline Null & $<0.001$ & NA & $<0.001$ & NA & 0.145 & NA \\
\hline
\end{tabular}

Piping frequency was based on 267 independent observations of individual trees pipe diameter and pipe ratio calculations were based on 229 observations as unpiped trees were excluded. AICc weight $\left(w_{i}\right)$ indicates the likelihood of the particular model being the best in the candidate set; AICc $w_{i}^{\prime}$ s sum to 1 over particular model set. The operator "+" indicates that only additive effects of the explanatory variables are in the model whereas the operator " $\times$ " indicates both main effects and interactions. AICc weights $>0.10$ are shown in bold, and these models were used to calculate model averaged coefficients. Explained deviance (expdev) is percent deviance explained by the model. NA is not applicable.

(i) Frequency of piping in 1985, in relation to tree size (diameter at breast height, dbh) and species $(n=267)$.

(ii) Piped diameter in 1985 in relation to dbh and species. For these analyses, we used only piped trees to avoid problems with zero-inflated data $(n=229)$. As expected, pipe diameter responses were dominated by $\mathrm{dbh}$. In further analyses we therefore scaled piped diameter by dividing by dbh, and termed this "pipe ratio".

(iii) Annual dbh increment (two annual increments, averaged) in response to initial $\mathrm{dbh}$, pipe ratio and species. Each tree thus constituted one observation ( $n=267)$.

(iv) Tree survival over 4 years in response to dbh, pipe ratio and species. Again, each tree constituted one observation $(n=267)$.

Generalised linear mixed effects models (GLMMs) and linear mixed effects models (LMEs) were used for all analyses. Plot was a random effect in all models, which allowed the use of all observations on individual trees whilst still accounting for the spatial grouping of the trees (Crawley, 2002). Binomial GLMMs with a logit link were used to investigate frequency of piping and tree survival, LMEs for piped diameter, pipe ratio and growth. The interaction between $\mathrm{dbh}$ and species was included in all the above analyses. The candidate model sets are listed in Tables 1 and 2 . We used the weighted averaged coefficients of all models receiving $\geq 10 \%$ of the AICc weight to calculate the predicted values presented in figures and tables.

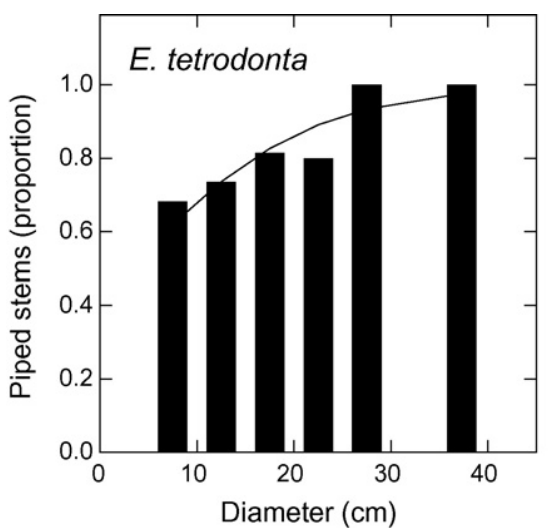

\section{Table 2}

Growth and survival of trees: AICc weights $\left(w_{i}\right)$ of models in candidate sets used to compare effects of pipe ratio (ratio pipe diameter: tree dbh), initial dbh (1985) and species (E. tetrodonta or E. miniata) on (i) growth rate of trees, and (ii) survival of trees over 4 years, based on 267 independent observations of individual trees

\begin{tabular}{|c|c|c|c|c|}
\hline \multirow[t]{2}{*}{ Response variable Model } & \multicolumn{2}{|c|}{ Growth } & \multicolumn{2}{|c|}{ Survival } \\
\hline & $w_{i}$ & Expdev (\%) & $w_{i}$ & Expdev $(\%)$ \\
\hline Initial $\mathrm{dbh}+\mathrm{Sp} \times$ ratio & 0.172 & 4.60 & 0.094 & 7.70 \\
\hline Initial $\mathrm{dbh}+\mathrm{Sp}+$ ratio & 0.113 & 3.40 & 0.210 & 7.40 \\
\hline Initial dbh + Species & 0.026 & 1.50 & 0.118 & 5.60 \\
\hline Initial $\mathrm{dbh}+$ Pipe ratio & 0.124 & 2.70 & 0.409 & 7.00 \\
\hline Initial dbh & 0.015 & 0.25 & 0.146 & 4.60 \\
\hline Species $\times$ Pipe ratio & 0.183 & 3.80 & 0.002 & 1.90 \\
\hline Species + Pipe ratio & 0.125 & 2.70 & 0.004 & 1.80 \\
\hline Species & 0.041 & 1.00 & 0.003 & 0.18 \\
\hline Pipe ratio & 0.170 & 2.10 & 0.008 & 1.30 \\
\hline Null & 0.031 & NA & 0.007 & NA \\
\hline
\end{tabular}

AICc weight $\left(w_{i}\right)$ indicates the likelihood of the particular model being the best in the candidate set; AICc weights sum to 1 over a particular model set. The operator "+" indicates that only additive effects of the explanatory variables are in the mode whereas the operator " $x$ " indicates both main effects and interactions. AICc weights $>0.10$ are shown in bold, and these models were used to calculate model averaged coefficients. Explained deviance (expdev) is percent deviance explained by the model. NA is not applicable.

\section{Results}

\subsection{Frequency of piping}

Eucalyptus tetrodonta showed a higher proportion of piping among large trees than among small trees (Fig. 1a). Eucalyptus miniata, however, was notable in that a high proportion of stems were piped regardless of size (Fig. 1b).

\subsection{Pipe diameter and pipe ratio}

Among trees that were piped, pipe diameter increased strongly with tree diameter ( $\mathrm{dbh}$ ), with little difference between the two species. Pipe ratio, however, did not change with dbh (averaging 0.31 in E. miniata and 0.27 in E. tetrodonta, over all sizes). This indicates that the size of a tree and the proportion of stem tissue lost to termites were independent.

\subsection{Tree growth and survival}

Overwhelmingly, termite-pipes were negatively correlated with size-dependent growth of Eucalyptus tetrodonta and with the probability of survival of either E. tetrodonta or E. miniata.

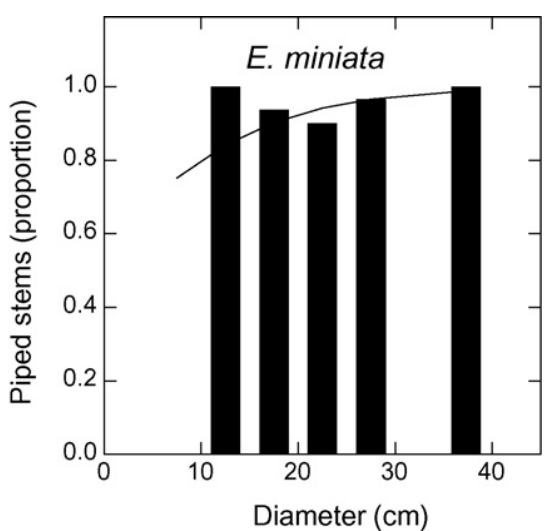

Fig. 1. Frequency of piped stems for six tree size classes $(5-10,10-15,15-20,25-30$, and $>30 \mathrm{~cm}$ dbh) for Eucalyptus. tetrodonta $(n=165)$ and for $E$. miniata $(n=102)$ in northern Australia. There were no E miniata trees 5-10 cm dbh. Bars show actual numbers; lines show model-averaged proportion of piped stems. 
Further, the relationships were strongly in proportion to the degree of piping.

Growth rates of unpiped trees of E. tetrodonta were higher than those of E. miniata, for any given dbh (Fig. 2a and b). For example, from modelled data, the growth rate of an unpiped $10 \mathrm{~cm}$ tree was $0.31 \mathrm{~cm}$ year $^{-1}$ for $E$. tetrodonta compared with 0.18 for $E$. miniata, and in a $40 \mathrm{~cm}$ tree, $0.37 \mathrm{~cm}_{\text {year }}^{-1}$ vs $0.24 \mathrm{~cm} \mathrm{year}^{-1}$ (Fig. 2a and b). However, with severe piping (e.g., pipe ratio of 0.80 ), the relative growth rates were reversed, with E. miniata growing slightly faster than E. tetrodonta: (e.g., $0.04 \mathrm{~cm}_{\text {year }}{ }^{-1}$ vs. $0.02 \mathrm{~cm}$ year $^{-1}$ for $10 \mathrm{~cm}$ trees and $0.10 \mathrm{~cm}_{\text {year }}{ }^{-1}$ vs. $0.08 \mathrm{~cm}_{\text {year }}{ }^{-1}$ for a $40 \mathrm{~cm}$ trees of E. miniata vs. E. tetrodonta, respectively) (Fig. 2a and b).

Larger pipe ratios were strongly associated with decreased growth rates, but only for E. tetrodonta (Fig. 2c). For example, the actual overall growth rate of $E$. tetrodonta trees that had no hollows averaged $0.266 \mathrm{~cm}_{\text {year }}{ }^{-1}$, compared to $0.203,0.078$ and $0.003 \mathrm{~cm}$ year $^{-1}$ for piped trees with less than $20,20-40$ and $>40 \%$ of their diameters hollowed out, respectively. In contrast, growth rates for E. miniata was not as sensitive to pipe ratio: corresponding growth rates were $0.166,0.092,0.193$ and $0.128 \mathrm{~cm} \mathrm{year}^{-1}$ (Fig. 2d).

Lower survival rates were also associated with smaller diameters and with large pipe ratios (Figs. 3 and 4). These relationships were similar for the two species, with only slightly higher survival for E. tetrodonta. By way of example using modelled data for the two species averaged together (Fig. 4), the survival rate of the smallest $(10 \mathrm{~cm} \mathrm{dbh})$ intact (unpiped) trees was $86 \%$. This steadily decreased across trees with a greater degree of piping, down to $64 \%$ in those small trees with $80 \%$ piping. Among $25 \mathrm{~cm}$ (dbh) trees, the comparison in survival was $96 \%$ vs. $87 \%$, for unpiped and $80 \%$ piping, respectively. Only among the largest trees
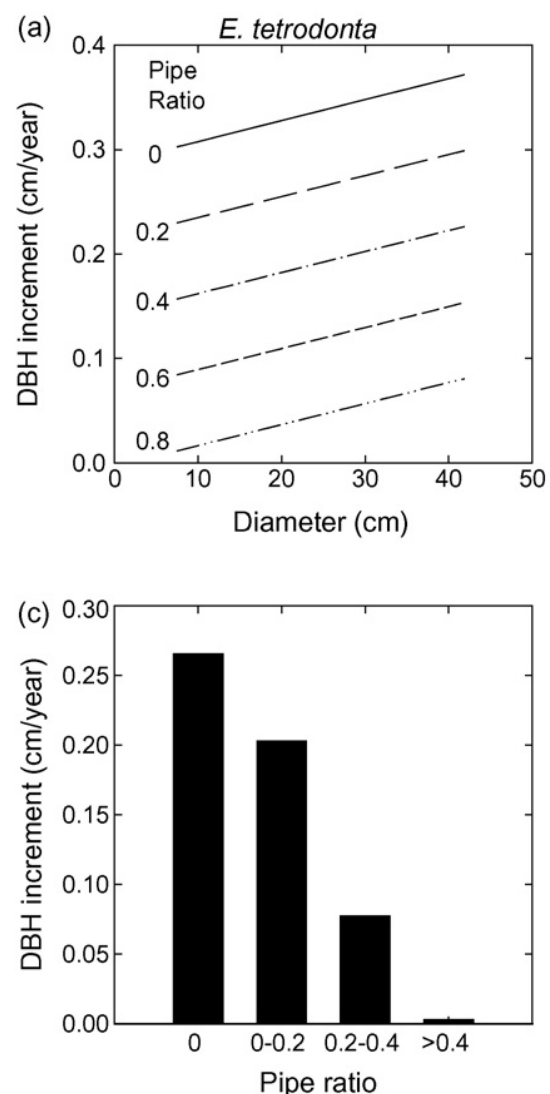

(40 cm dbh) was 4-year survival 97-99\% without much difference among pipe ratios (Fig. 4).

In sum, the smallest trees will thrive only if the loss of stem to termites is small. When $E$. tetrodonta trees are less than $20 \mathrm{~cm} \mathrm{dbh}$, any piping greater than $60 \%$ of the diameter (pipe ratio $\geq 0.60$ ) is accompanied by no or very little growth and less than $75 \%$ probability of survival. When trees are even smaller, say, $10 \mathrm{~cm}$ $\mathrm{dbh}$, any piping greater than $60 \%$ of the diameter $(6 \mathrm{~cm})$ essentially stops growth, and reduces survival greatly (Fig. 4). Once a eucalypt achieves a diameter greater than $30 \mathrm{~cm}$, growth rate continues to increase compared to smaller sizes, and the probability of death becomes nearly independent of degree of piping.

\section{Discussion}

\subsection{Contrasts between E. tetrodonta and E. miniata}

Eucalyptus miniata was unlike other savanna species investigated by Werner and Prior (2007) in that small trees were almost always piped, more than $85 \%$, a frequency similar to that of large trees. Thus, even random selection of $E$. miniata trees for harvest would yield $85 \%$ piped trees. On the other hand, the frequency of piping in E. tetrodonta stems, while less overall than in E. miniata, was still high enough ( $>60 \%$ in all size classes) for this species to be attractive for harvesting for didgeridoo manufacture. While $E$. phoenicea $\mathrm{F}$. Muell. (the third species important for didgeridoo manufacture; Whitehead et al., 2006) was not found in the study area, it is very closely related to E. miniata (Dunlop et al., 1995), and it would be interesting to investigate whether frequency of piping and relationships among size, pipe ratio, life history, and survival are similar.
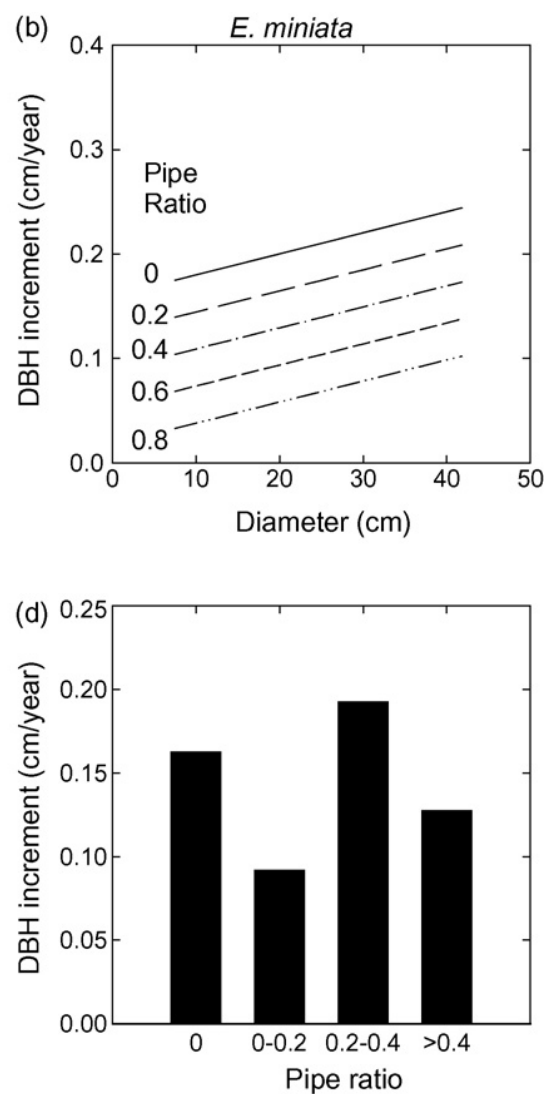

Fig. 2. Growth (dbh increment) of canopy eucalypts of northern Australia as a function of tree diameter (dbh) across a range of pipe ratios: modelled values for Eucalyptus tetrodonta (a) and E. miniata (b) and field data for E. tetrodonta (c) and E. miniata (d). 

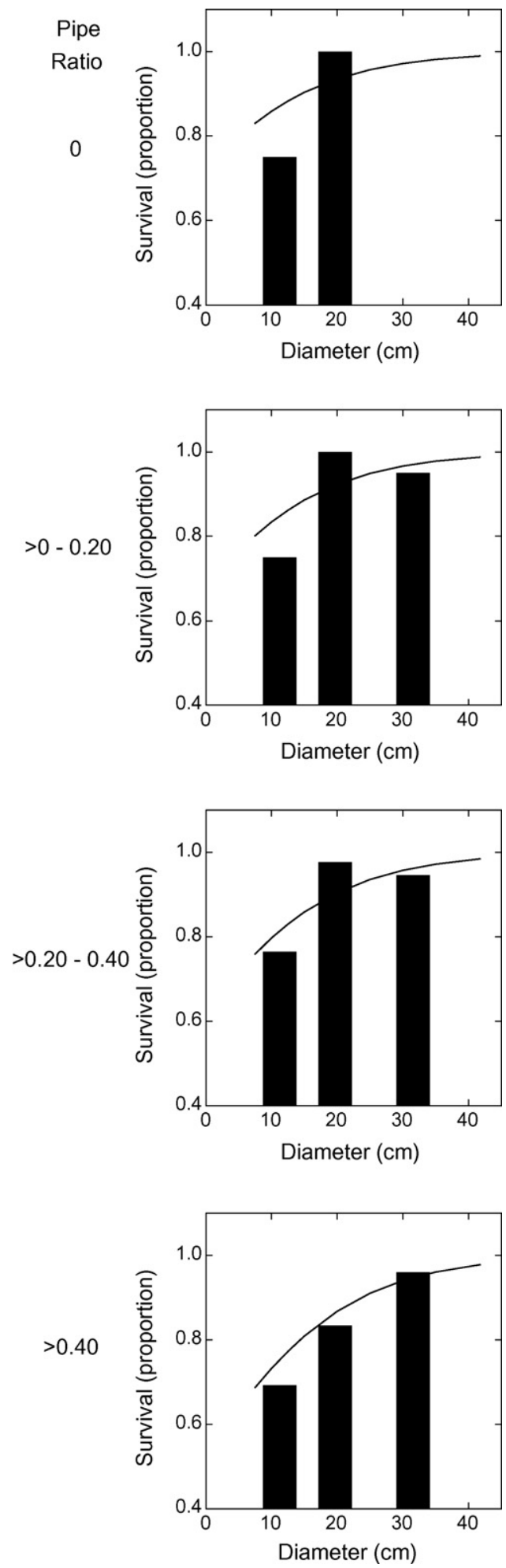

Fig. 3. Four-year survival (proportion) of individual trees of Eucalyptus tetrodonta and E. miniata averaged together, for three diameter (dbh) classes $(<15 \mathrm{~cm} \mathrm{dbh}, 15-$ $25 \mathrm{~cm} \mathrm{dbh}$, and $>25 \mathrm{~cm} \mathrm{dbh}$ ) and four pipe ratio classes (zero piping, $>0-0.10$ $>0.10-0.40$, and $>0.40$.) Only classes containing $>10$ individual trees are shown. Bars show actual numbers; lines show the model-averaged proportion of trees that survived.

Other studies of growth rates of Eucalyptus minata and E. tetrodonta all have reported that $E$. minata trees grew faster on average, than E. tetrodonta trees (Werner and Murphy, 2001; Cook et al., 2005; Werner, 2005; Prior et al., 2006). It is important to

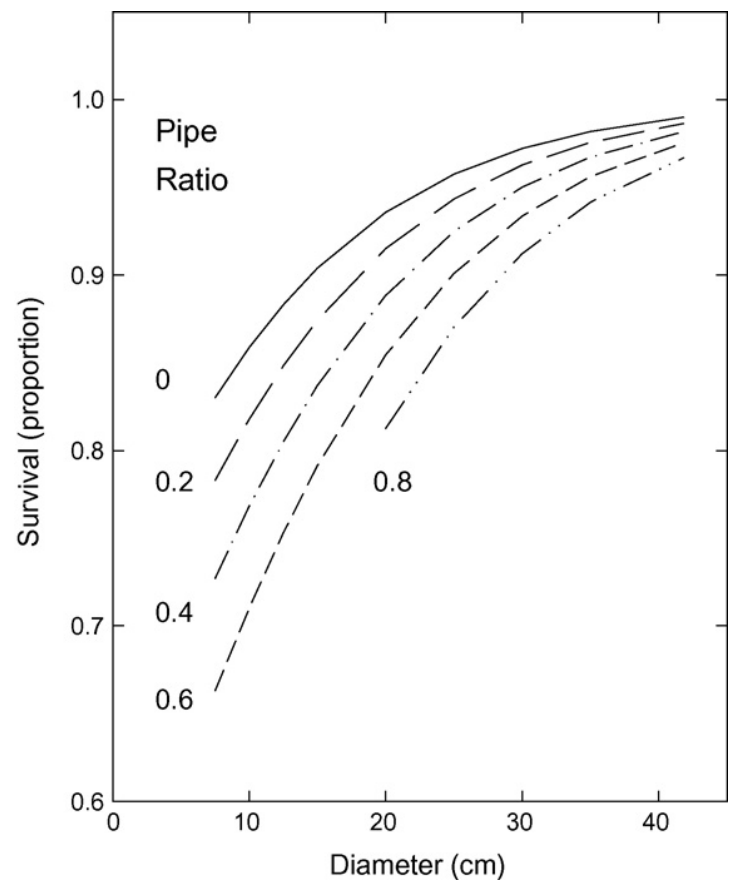

Fig. 4. Four-year survival (proportion) of Eucalyptus tetrodonta and E. miniato averaged together: modelled values of survival as a function of tree diameter, for a range of pipe ratios. No eucalyptus $<20 \mathrm{~cm}$ dbh had a pipe ratio $>0.6$.

point out that these studies all measured trees without regard for termite piping. We have shown that when termite pipes are absent (e.g., no trees are piped), the opposite is true-E. tetrodonta trees actually grow faster than do E. minata trees. Indeed, E. miniata grows faster then $E$. tetrodonta only when both are piped to a comparable degree.

Although it is impractical in most basic population dynamics and/or growth studies to sample all trees for termite piping, researchers will want to recognize that differences in growth and/or survival rates among various stands of trees may not be due only to intrinsic site differences but to the degree of termite presence and activity. This possibility has not been calculated or investigated in the field. Quantitative information on recruitment, growth and survival is important in setting sustainable harvest quotas for didgeridoos and any other non-timber products from these species.

The differences between E. miniata and E. tetrodonta in frequency of termite piping (at least for trees $<25 \mathrm{~cm} \mathrm{dbh}$ ), and the sensitivities of growth rate to degree of piping (pipe ratio) are yet two more differences between these often co-dominant canopy species, adding to differences in gross morphology, carbon allocation, bark thickness and type, reproductive phenology, growth rates and many aspects of hydraulic conductance and water use (Setterfield and Williams, 1996; Myers et al., 1997; Werner and Murphy, 2001; Werner, 2005; Cernusak et al., 2006). The ecological significance of most of these species differences is unknown, although hollow stems seem to indicate relative disadvantages to small trees in the form of lower growth and survival (Figs. 2 and 3) and to larger trees in the form of lower survival in the face of high winds or severe fire (Stocker, 1976; Lonsdale and Braithwaite, 1991; Williams et al., 1999).

4.2. Traditional vs. commercial tree harvesting for didgeridoos and potential long-term impacts

Aboriginal people make up almost $30 \%$ of the Northern Territory's population and own over half of the land, mainly 
under communal title. Few opportunities for economic development exist, but substantial incomes are generated from natural resources on the land (Gorman et al., 2006). Beyond the larger sources of income from mining and eco-tourism are the developing areas of non-timber products from savanna woodlands including seeds for horticultural purposes and wood for the ever-increasing international demand for didgeridoos. Didgeridoos for sale in the marketplace are made from wood harvested by both traditional and commercial methods. The traditional and commercial methods are very different, and given the findings of the current study, deserve attention.

An experienced harvester using traditional Aboriginal methods will use several means (including knocking) to determine the presence and approximate size of any hollow before a selected tree is felled, with remarkable accuracy. A pipe of approximately $8 \mathrm{~cm}$ diameter is usually accepted for further processing (Cloake, 2002). In one study of traditional harvesting of $E$. tetrodonta for didgeridoos on the Wanguri clan estate in North East Arnhem Land, the tree selected ranged from 7.5 to $12.9 \mathrm{~cm}$ dbh (Taylor and Baker, 2002b). Ninety-eight percent of didgeridoos made by the Yolngu people of North East Arnhem Land are made from the main trunk of small trees of E. tetrodonta and E. miniata, the two most common canopy trees in the area (Cloake, 2002). In a further study, traditional harvesting of trees by Yolngu and Jawoyn (east of Katherine, Northern Territory) were compared by Taylor et al. (2002). Harvesters selected trees for didgeridoos from the most common species of their respective lands, E. tetrodonta and $E$. phoenicea. The mean sizes of harvested stems (approximately $1.3 \mathrm{~m}$ in length) were similar: $10.4-14.9$ and $6.5-7.5 \mathrm{~cm}$ diameter (top and bottom diameter, Yolngu and Jawoyn, respectively), with hollows of 3.1-9.2 and 3.0-3.7 cm diameter (top and bottom hollow diameter, Yolngu and Jawoyn, respectively) (Taylor et al., 2002).

In sum, the size range of trees taken during traditional harvesting are almost all less than $13-15 \mathrm{~cm} \mathrm{dbh}$, and have pipe ratios of $\geq 0.5$, up to 0.8 . Among these smaller size classes, one could expect proportionally more E. miniata trees to be piped than $E$. tetrodonta trees. Far more E. tetrodonta trees are used for traditionally made didgeridoos, however, than are E. miniata, both because of the preferred acoustical qualities and higher densities of small trees in stands of E. tetrodonta (Cloake, 2002; Taylor and Baker, 2002b).

Most importantly, our results indicate that trees with this degree of piping (pipes ratios $\geq 0.5$, up to 0.8 ), would have zero to very low growth rates, and a low probability of survival had they not been harvested ( $11 \%$ deaths per year, on average, even without fire). That is, the Aboriginal traditional method of harvesting didgeridoos, where smaller trees are selected on the basis of acoustical qualities, inadvertently also selects those trees which are most likely going to die before reaching maturity even without being harvested.

This is in contrast to non-traditional methods of harvesting didgeridoos in large-scale commercial operations, which target a wider range of trees, including those trees with substantial growth rates and high probability of long-term survival. The availability of modern machinery and a wider variety of tools, in combination with a large, but less discerning external market, has resulted in less discriminating selection of trees for harvest (Forner, 2006). By way of example, in a study of harvesting using mainly commercial, non-traditional methods on Jawoyn lands in drier and rockier habitats east of Katherine, Northern Territory, didgeridoos were cut mainly from branches of larger trees (up to $38 \mathrm{~cm}$ dbh, with an average of $16 \mathrm{~cm} \mathrm{dbh}$ ), rather than the smaller main stems (5-1 ratio of branches to main stems) (Forner, 1999, 2006; Taylor and Baker, 2002b). Although half of these harvested trees resprouted shortly after harvest (Forner, 1999), the fate and vigour of the resprouts is unknown. From knowledge of the limited growth and survival of resprouts (Werner et al., 2006; unpublished data), we suggest that the larger trees carried the greatest potential for longterm sustainable populations, at least demographically and perhaps genetically.

In general, the impact of current commercial harvesting of trees on the population dynamics of eucalypts has yet to be calculated. We are not advocating that commercial production of didgeridoos cease as they are an important source of new livelihoods and of economic importance to the remote localities of the region, but rather that the traditional selection methods be incorporated more fully into field operations. As pointed out by Taylor and Baker (2002a) and Forner (2006), the current international high demand, especially in Europe and North America, for didgeridoos from "natural sources", added to an illegal harvest estimated at twice the level of legal harvest (in the tens of thousands of trees annually), will undoubtedly have adverse long-term consequences for both regional eucalypt populations and Aboriginal communities.

\section{Conclusion}

This paper provided evidence of both similarities and differences between the two dominant canopy trees, E. tetrodont $a$ and $E$. miniata, in north Australian savannas in their responses to tree piping termites, therein increasing our basic knowledge of these co-occurring species. The finding that growth and survival rates are both size-dependent and related to degree of stem piping has implications for havesting methods of trees that target particular sizes of trees. The longer-term demographic consequences of various harvesting techniques, coupled with the large number of trees being harvested annually, are beyond the scope of this paper, but are vitally important to consider for long-term sustainability of local populations of these important tree species.

\section{Acknowledgements}

The field work was initiated with funding by the USA Man and Biosphere Program via the US Forest Service, Pacific Region (Grant no. 59-PSW-82-005-G to Michigan State University, P.A. Werner and P.G. Murphy). L.D. Prior was supported by Australian Research Council Grant DP 0343000. We are grateful to John Estbergs of CSIRO who, with the assistance of Gus Wangeneen, Ricky Fletcher, Graham Pang Quee, and Jack Cusack (dec.), cored the trees and took all measurements relating to termites, and to Jack Cusack of CSIRO for tree identification and assistance with tree diameter measurements. We thank James Shirley for synthesizing a database from diverse field sheets and for constructive comments on earlier drafts of the paper.

\section{References}

Andersen, A.N., Cook, G.D., Williams, R.J. (Eds.), 2003. Fire in Tropical Savannas: The Kapalga Experiment. Springer-Verlag, New York, 195 pp.

Andersen, A.N., Jacklyn, P., Dawes-Gromadzki, T., Morris, I., 2005. Termites of Northern Australia. CSIRO and Tropical Savannas CRC. Barker, Publisher, Alice Springs, NT, Australia, 44 pp.

Braithwaite, R.W., 1985. The Kakadu Fauna Survey: An Ecological Survey of Kakadu National Park. Final report to the Australian National Parks and Wildlife Service, Canberra, ACT, Australia, 1291 pp.

Braithwaite, R.W., Miller, L., Wood, J.T., 1988. The structure of termite communities in the Australian tropics. Austral Ecol. 13, 375-391.

Burnham, K.P., Anderson, D.R., 2002. Model Selection and Multimodel Inference: A Practical Information-Theoretic Approach. Springer, New York, 488 pp.

Cernusak, L.A., Hutley, L.B., Beringer, J., Tapper, N.J., 2006. Stem and leaf gas exchange and their responses to fire in a north Australian tropical savanna. Plant Cell Environ. 29, 632-646. 
Cloake, J., 2002. Yadaki (didjeridu) of the Yolngu people of North East Arnhem Land. In: Taylor, R. (Ed.), Harvesting of Didjeridu by Aboriginal People and thei Participation in the Industry in the Northern Territory: Report to AFFA Australia. Northern Territory Parks and Wildlife Service, Department of Infrastructure, Planning and Environment, Palmerston, NT, Australia, pp. 15-24.

Cook, G.D., Liedloff, A.C., Eager, R.W., Chen, X., Williams, R.J., O'Grady, A.P., Hutley, L.B., 2005. The estimation of carbon budgets of frequently burnt tree stands in savannas of northern Australia, using allometric analysis and isotopic discrimination. Aust. J. Bot. 53, 621-630.

Crawley, M.J., 2002. Statistical Computing: An Introduction to Data Analysis Using S-Plus. Wiley, Chichester, UK, 761 pp.

Dunlop, C.R., Leach, G.J., Cowie, I.D., 1995. Flora of the Darwin Region. Conservation Commission of the Northern Territory, Darwin, NT, Australia.

Findlayson, C.M., von Oertzen, I. (Eds.), 1996. Landscape and vegetation ecology of the Kakadu region, northern Australia, Kluwer Academic Publishers, Dordrecht, $239 \mathrm{pp}$.

Forner, J. 1999. Harvesting of Eucalyptus phoenicea for Didjeridu Production: Use of Remote Sensing and GIS to Map a Cultural and Natural Resource. Honours thesis, Charles Darwin University, Darwin, NT, Australia.

Forner, J., 2006. The globalization of the didjeridu and the implications for smal scale community based producers in remote northern Australia. Int. J. Environ. Cult. Econ. Soc. Sustain. 2, 137-148. www.sustainability-journal.com.

Fox, R.E., Clark, N.B., 1972. The incidence of termites in eucalypts of the Darwin area Aust. For. Res. 5, 29-36.

Gorman, J.T., Griffiths, A.D., Whitehead, P.J., 2006. An analysis of the use of plant products for commerce in remote aboriginal communities of northern Australia. Econ. Bot. 60, 362-373.

Hodda, M., 1992. Ecology of Termites in Savanna at Kapalga, N. T., Australia. Ph.D. Thesis. Australian National University, Canberra, ACT, Australia. 258 pp.

Lehmann, C.E.R., 2007. Tropical Mesic Savanna Dynamics in Kakadu National Park Ph.D. Thesis. Charles Darwin University, Darwin, NT, Australia.

Lonsdale, W.M., Braithwaite, R.W., 1991. Assessing the effects of fire on vegetation in tropical savannas. Aust. J. Ecol. 16, 363-374.

Myers, B.A., Duff, G.A., Eamus, D., Fordyce, J.R., O’Grady, A., Williams, R.J., 1997. Seasonal variation in water relations of trees of differing leaf phenology in a wet-dry tropical savanna near Darwin, northern Australia. Aust. J. Bot. 45, 225240.

Prior, L.D., Brook, B.W., Williams, R.J., Werner, P.A., Bradshaw, C.J.A., Bowman, D.M.J.S., 2006. Environmental and allometric drivers of tree growth rates in a north Australian savanna. For. Ecol. Manage. 234, 164-180.

R-Development Core Team, 2005. R: A Language and Environment for Statistica Computing. R Foundation for Statistical Computing, Vienna, Austria. http:// www.r-project.org/foundation/.

Russell-Smith, J., 1995. Flora. In: Press, T., Lea, D., Webb, A., Graham, A. (Eds.), Kakadu. Natural and Cultural Heritage and Management. Australian Nature Conservation Agency and North Australia Research Unit, Canberra, Australia, pp. 127-166.
Russell-Smith, J., Needham, S., Brock, J., 1995. The physical environment. In: Press, T., Lea, D., Webb, A., Graham, A. (Eds.), Kakadu. Natural and Cultural Heritage and Management. Australian Nature Conservation Agency and North Australia Research Unit, Canberra, Australia, pp. 94-127.

Setterfield, S.A., Williams, R.J., 1996. Patterns of flowering and seed production in Eucalyptus miniata and E. tetrodonta in a tropical savanna woodland, Northern Australia. Aust. J. Bot. 44, 107-122.

Stocker, G.C. 1976. Report on Cyclone Damage to Natural Vegetation in the Darwin Area after Cyclone Tracy, 25 December 1974. Australian Government Publishing Service, Canberra, 39 pp.

Taylor, R., Baker, B., 2002a. Standing crop and harvest levels of didjeridu stems on the Wanguri clan estate, North East Arnhem Land. In: Taylor, R. (Ed.), Harvesting of Didjeridu by Aboriginal People and Their Participation in the Industry in the Northern Territory: Report to AFFA Australia. Northern Territory Parks and Wildlife Service, Department of Infrastructure, Planning and Environment, Palmerston, NT, Australia, pp. 32-41.

Taylor, R., Baker, B., 2002b. Production and sales of didjeridu in the Northern Territory. In: Taylor, R. (Ed.), Harvesting of Didjeridu by Aboriginal People and Their Participation in the Industry in the Northern Territory: Report to AFFA Australia. Northern Territory Parks and Wildlife Service, Department of Infrastructure, Planning and Environment, Palmerston, NT, Australia, pp. 43-51.

Taylor, R. Cloake, J., Forner, J., 2002. Harvesting rates of a Yolgnu harvester and comparison of selection of didjeridu by the Yolngu and Jawoyn. In: Taylor, $R$. (Ed.), Harvesting of Didjeridu by Aboriginal People and Their Participation in the Industry in the Northern Territory: Report to AFFA Australia. Northern Territory Parks and Wildlife Service, Department of Infrastructure, Planning and Environment, Palmerston, NT, Australia, pp. 25-31.

Werner, P.A., 2005. Impact of feral water buffalo and fire on growth and survival of mature savanna trees: an experimental field study in Kakadu National Park, northern Australia. Austral Ecol. 30, 625-647.

Werner, P.A., Murphy, P.G., 2001. Size-specific biomass allocation and water content of above- and below-ground components of three Eucalyptus species in a northern Australian savanna. Aust. J. Bot. 49, 155-167.

Werner, P.A., Prior, L.D., 2007. Tree-piping termites and growth and survival of host trees in savanna woodland of north Australia. J. Trop. Ecol. 23, 611-622.

Whitehead, P.J. Gorman, J., Griffiths, A.D., Wightman G., Massarella, H., Altman J., 2006. Feasibility of Small Scale Commercial Native Plant Harvests by Indigenous Communities. Final Report to Rural Industries Research Development Enterprise, RIRDC Publication Number 04/149, Land \& Water Australia. Canberra, Australia. $197 \mathrm{pp}$.

Wilson, B.A, Russell-Smith, J, Williams, R, 1996. Terrestrial vegetation. In: Findlayson, C.M., von Oertzen, I. (Eds.), Landscape and vegetation ecology of the Kakadu region, northern Australia. Kluwer Academic Publishers, Dordrecht, 57 79.

Williams, R.J., Cook, G.D., Gill, A.M., Moore, P.H.R., 1999. Fire regime, fire intensity and tree survival in a tropical savanna in northern Australia. Aust. J. Ecol. 24, $50-59$. 